\title{
OMASAL MORPHOLOGY OF DAIRY COWS FED WITH HIGH OR LOW GRAIN CONTENT DIET PRIOR PARTURITION
}

\author{
Morfologia omasal de vacas leiteiras alimentadas com dieta contendo \\ alto ou baixo teor de grãos antes do parto
}

\author{
Danilo de Oliveira Rocha Bhering Santoro ${ }^{1}$, João Chrysostomo Resende Júnior ${ }^{2}$, Ronaldo Francisco de Lima ${ }^{3}$, \\ João Luiz Pratti Daniel ${ }^{4}$, Matheus Balduíno Moreira ${ }^{5}$, Suely de Fátima Costa ${ }^{6}$
}

\begin{abstract}
Little is known about the morphological response of the omasum in dairy cows that consume a high-energy diet pre-partum. The aim of this study was to investigate whether a transitional diet with high grain content is able to induce changes in omasum morphology. Six weeks before the expected calving, four Holstein cows were fed a standardization diet, and four weeks before delivery, the cows were fed a diet with high grain content (HGC) or low (LGC) grain content. After calving, all of the cows were fed a high energy lactation diet. The cows that were fed the HGC diet pre-partum had higher dry matter and nutrient intake than the cows that were fed the LGC diet. The mitotic index of the omasum epithelium was higher than the mitotic index in the rumen, but apparently the response to the diet stimuli was slower. In the cows that were fed the HGC diet, the omasum papillae were taller one week before parturition and two weeks post-partum. Cows that were fed the HGC diet had a thinner epithelium due to thinner non-keratinized layers of the omasum epithelium. We conclude that the omasum mucosa of dairy cows responds to the stimuli of a pre-partum HGC diet, which was indicated by the greater height of the omasum papillae and by the reduced thickness of the omasum epithelium. It seems that the mitotic index responds a little more slowly, but the response to the diet stimuli is stronger in the omasum epithelium than in the rumen.
\end{abstract}

Index terms: Transition period; unguiculiform papillae; digestive disturbance.

\section{RESUMO}

Pouco é conhecido a respeito da resposta morfológica do omaso de vacas leiteiras que consomem dieta alta em energia no pré-parto. Este estudo visou investigar se a dieta de transição com alto teor de grãos induz mudanças na morfologia do omaso. Seis semanas antes do parto esperado, quatro vacas Holandesas foram alimentadas com uma dieta de padronização e a partir de quatro semanas antes foram alimentadas com dieta com alto (ATG) ou baixo (BTG) teor de grãos. Após o parto, todas as vacas foram alimentadas com dieta lactacional de alta energia. As vacas que foram alimentadas com ATG antes do parto tiveram maior ingestão de matéria seca e de nutrientes do que as vacas que foram alimentadas com BTG. O índice mitótico (IM) do epitélio do omaso foi mais alto do que o do rúmen, mas aparentemente a resposta ao estímulo da dieta foi mais lenta. As papilas do omaso nas vacas que foram alimentadas com ATG foram mais altas uma semana antes e duas semanas após o parto. As vacas que foram alimentadas com ATG tiveram o epitélio do omaso menos espesso devido à menor espessura das camadas não queratinizadas. Concluímos que a mucosa do omaso de vacas leiteiras responde ao estímulo da dieta com ATG fornecida antes do parto, indicado pela maior altura das papilas e menor espessura do epitélio. Parece que o IM responde mais lentamente, porém mais fortemente ao estímulo da dieta no omaso do que no rúmen.

Termos para indexação: Período de transição; papilas unguiculiformes; distúrbios digestivos.

\section{INTRODUCTION}

In dairy cows, metabolic disturbances are common during the period between three weeks before and three weeks after parturition and achieving productive performance potential becomes difficult (Grummer, 1995). Increasing the grain content of the diet during the last three weeks of gestation in highly productive dairy cows as a way to prepare them for lactation has been accepted for more than eighty years. These dairy cows receive a high calorie lactation diet after calving. These diets are rich in carbohydrates that are quickly fermentable in the reticulorumen and lead to rapid production of volatile fatty acids (VFAs). If the reticulorumen epithelium is

${ }^{1}$ Nutrimentos Santa Maria LTDA/Nutrisamal - Santa Maria de Jetibá - ES - Brasil

2Universidade Federal de Lavras/UFLA - Departamento de Medicina Veterinária/DMV - Cx. P. 3037 - $37200-000$ - Lavras - MG - Brasil joaocrj@dmv.ufla.br

${ }^{3}$ Universidade Federal do Amazonas/UFAM - Campus Parintins - Instituto de Ciências Sociais, Educação e Zootecnia - Parintins - AM - Brasil

${ }^{4}$ Universidade Estadual de Maringá/UEM - Departamento de Zootecnia - Maringá - PR - Brasil

${ }^{5}$ Recursos Humanos no Agronegócio/REAHAGRO - Belo Horizonte - MG - Brasil

${ }^{6}$ Universidade Federal de Lavras/UFLA - Departamento de Medicina Veterinária/DMV - Lavras - MG - Brasil

Received in march 18, 2015 and approved in may 22, 2015

Ciênc. Agrotec., Lavras, v. 39, n. 6, p. 583-592, nov./dez., 2015 
not prepared to remove the VFAs at the same velocity at which they are produced, the VFAs accumulate in the ruminal environment, causing rumen acidosis (Barker; Van Dreumel; Palmer, 1995). The VFAs produced in the reticulorumen are removed by absorption through the rumen wall and by passage to the omasum, where they are incorporated into the fluid phase.

Supply of a pre-partum, high calorie diet is able to induce rumen epithelium proliferation (Teófilo et al., 2011), which contributes to rumen acidosis control (Dirksen et al., 1984) by causing the necessary post-partum adaptation for the absorption of high VFA concentrations. However, there is no information about the morphological response of the omasum to pre-partum high calorie diets in dairy cows, even though the omasum receives approximately $40 \%$ to $45 \%$ of the VFAs produced in the rumen (Resende Júnior et al., 2006). It is likely that extension of the absorptive surface of the omasum is important for VFA absorption by decreasing the amount that passes to the abomasum. The absorption of excess VFAs in the abomasum is correlated with a decrease in motility, which is a precursor to digestive disturbances such as abomasum displacement (Bolten et al., 1976; Svedsen, 1969).
The purpose of this work was to investigate whether supply of a transitional diet with high grain content during the late pre-partum weeks is able to induce changes in the morphology of the omasum mucosa that could result in lower post-partum digestive disturbances in dairy cows.

\section{MATERIALS AND METHODS}

All procedures were approved by the Bioethical Committee for Animal Utilization at the Federal University of Lavras. Four Holstein cows averaging $487 \pm 49 \mathrm{~kg}($ mean \pm SE) had a silicone cannula four inches in diameter surgically placed in the rumen dorsal sac and were allocated to two treatments. Six weeks before expected parturition, the cows had their lactation terminated and were housed in a tie stall with a sand bed. They were then fed a standardization diet according to the requirements provided by the NRC (2001). Four weeks before the expected calving, the cows were fed either a diet containing high grain content (HGC) or a diet containing low grain content (LGC) (Table 1). After parturition, all of the cows received the same diet, which was formulated according to the NRC requirements (2001).

Table 1: Composition of the standardization diet, high grain content (HGC) diet, low grain content (LGC) diet and lactation diet provided over the experimental period.

\begin{tabular}{ccccc}
\hline Feed (\% of DM) & Standardization & HGC & LGC & Lactation \\
\hline Corn silage & 98.2 & 58.2 & 98.2 & 40.3 \\
Soybean meal & - & 13.3 & - & 18.1 \\
Ground corn & - & 26.7 & - & 20.1 \\
Urea & 1.0 & 1.0 & 1.0 & 0.3 \\
Mineral and vitamin Premix & 0.8 & 0.8 & 0.8 & 1.0 \\
Citrus pulp & - & - & - & 5.9 \\
Cotton seed & - & - & - & 14.3 \\
\hline Nutrients (\% of DM) & & & & \\
Crude protein (CP) & 8.8 & 16.0 & 8.8 & 18.7 \\
Neutral detergent fiber (NDF) & 58.9 & 38.9 & 58.9 & 36.6 \\
Ether extract (EE) & 3.1 & 3.2 & 3.1 & 5.4 \\
Mineral Matter (MM) & 5.1 & 4.6 & 5.1 & 5.2 \\
Non-fiber carbohydrate (NFC) & 24.1 & 37.3 & 24.1 & 34.1 \\
Forage NDF & 58.9 & 34.9 & 58.9 & 24.12 \\
Forage: Concentrate ratio & $100: 0$ & $61: 39$ & $100: 0$ & $40: 60$ \\
Net energy (Mcal/kg of DM) & 1.33 & 1.59 & 1.33 & 1.71 \\
Total digestible nutrients (TDN) ${ }^{1}(\%)$ & 58.9 & 67.6 & 58.9 & 71.1 \\
\hline
\end{tabular}

${ }^{1} \mathrm{NFC}=100-(\mathrm{CP}+\mathrm{NDF}+\mathrm{EE}+\mathrm{MM}) .{ }^{2} \mathrm{TDN}=(((\mathrm{LE} / \mathrm{kg} \mathrm{DM}+0.12) / 0.0245) / 100) \times 1.1$. 
The diet was offered twice a day, at 7:00 a.m. and 4:00 p.m., and an estimate of consumption was conducted daily. After parturition, the cows were milked twice a day, at 6:00 a.m. and 4:00 p.m., and milk production was measured at each milking.

At days $-42,-28,-14,-7,2,14,28,42$ and 56 relative to parturition, the reticulorumen was evacuated, and biopsies of approximately $1 \mathrm{~cm}^{2}$ of the wall of the rumen ventral sac (recessus ruminis) and from a lamina of the omasum (lamina omasi) were conducted. The biopsies of the rumen were performed using surgical scissors after the exteriorization of the rumen mucosa through the cannula. The omasum laminae were accessed through the ostium reticulo-omasicum by introduction of the researcher's hand through the rumen cannula, and the biopsies were performed using a device similar to pliers (Lima et al., 2011). The rumen and omasum fragments were fixed in Bouin's liquid for $22 \mathrm{~h}$ and stored in alcohol at $70^{\circ} \mathrm{GL}$ until routine histological processing. The height and area of the omasum papillae (Papillae omasi) and the mitotic index (MI) of the basal layer of the rumen epithelium were estimated in $5 \mu \mathrm{m}$ thick sections stained by hematoxylin and eosin. For measurements of the thicknesses of the keratinized layer (TKL) of the epithelium and the nonkeratinized layer (TNKL) of the epithelium, the fragments were stained by Masson's trichrome. The height and area of the omasum papillae, the TKL, and the TNKL were measured in images captured by a digital camera attached to a light microscope. For height and area determination, the pictures were captured using 40x magnification. For TKL and TNKL determination, 400x magnification was used. These morphometric variables were analyzed using cell$^{\wedge} \mathrm{B}$ basic imaging software (Olympus, Hamburg Germany). Using a light microscope at 400x magnification, the nuclei of 2000 cells of the rumen epithelium basal layer and of the omasum lamina were counted. All nuclei showing mitotic figures were reported, and the mitotic index was calculated as a percentage of the total counted nuclei. The TKL and TNKL measurements were performed using a light microscope at 400x magnification. Four measurements per fragment were performed in randomized fields of the omasum mucosa.

The data regarding dry matter intake (DMI) and nutrient consumption, the rumen MI, the omasum MI, and the height, width, and area of the TKL and TNKL of the omasum epithelium were analyzed using the MIXED procedure of the statistical package SAS (SAS Inst. Inc., Cary, NC), according to the following model: $\mathrm{Y}_{\mathrm{ijk} \mathrm{l}}=\mu+\mathrm{C}_{\mathrm{i}}+\mathrm{G}_{\mathrm{j}}+\mathrm{D}_{\mathrm{k}}+$ $\mathrm{GD}_{(\mathrm{ik})}+\mathrm{e}_{\mathrm{ijk}}$, where $\mathrm{Y}_{\mathrm{ijkl}}:$ dependent variable; $\mu$ : overall mean; $\mathrm{C}_{\mathrm{i}}$ : cow as randomized effect $(\mathrm{i}=4) ; \mathrm{G}_{\mathrm{j}}$ : effect of the grain content of the pre-partum diet $(j=$ high or low $) ; D_{k}$ : effect of the collection day $(\mathrm{k}=9) ; \mathrm{GD}_{(\mathrm{ik})}$ : effect of the interaction between diet grain content and collection day; $\mathrm{e}_{\mathrm{ij} \mathrm{j}}$ : residual error. The cows within each treatment were used as the error term to test treatment effects. For the statistical analysis of milk production, corrected milk production, milk fat, and milk protein production, the same model was used, but only the post-partum days $(\mathrm{k}=5)$ were considered. For the statistical analysis of the mitotic index in both compartments of the stomach, the same model was used, but a compartment effect (omasum or rumen) was included in the model.

\section{RESULTS AND DISCUSSION}

The cows fed the HGC diet before parturition had higher DMI/kg of body weight (DMIBW) than the cows fed the LGC diet (Table 2) for the entire experimental period. The most marked difference occurred in the first four weeks after calving (Figure 1). The cows fed the HGC diet before calving increased DMI more acutely post-partum than the cows fed the LGC diet before parturition. Higher DMIBW led to higher intake of all nutrients/ $\mathrm{kg}$ of body weight by the cows that were fed the HGC diet pre-partum compared to cows that were fed the LGC diet, which supports the theory of better health for those animals (Table 2).

However, the $3.5 \%$ fat-corrected milk yield, the milk fat yield, and the milk protein yield did not differ between treatments. There was only a highly significant effect of the day after calving (Table 2), reflecting a normal lactation curve with numerically higher milk yield in the cows that were fed the HGC diet and had higher DMI before parturition (Table 2). Similarly, Guo, Peters and Kohn (2007) comparing pre-partum diets with different caloric content, did not observe differences in milk yield, milk composition, body weight and body condition over the post-partum period.

Apossible explanation for the effect of the transitional diet on post-partum DMIBW could be the adaptation of the rumen epithelium (Melo et al., 2013; Teófilo et al., 2011; Dirksen et al., 1984). This adaptation could have induced higher synchrony between the production and removal of VFAs in the reticulorumen, which enables greater equilibrium in the rumen environment, with a $\mathrm{pH}$ that is more stable and closer to normality. These factors induce better animal health and productive performance because sub-acute rumen acidosis has a negative effect on DMI (Elliot et al., 1995). In addition to its negative effects on food intake (Elliot et al., 1995), rumen acidosis also negatively interferes with rumen fiber degradation (Grant; Mertens, 1992), rumen motility (Crichlow; Chaplin, 1985), and rumen wall morphology (Gäbel; Aschenbach; Muller, 2002). 
Table 2: Parameters of feed and production of Holstein cows consuming diet containing high (HGC) or low (LGC) grain content prepartum and a highly caloric postpartum diet.

\begin{tabular}{|c|c|c|c|c|c|c|}
\hline \multirow{2}{*}{ Variable } & \multicolumn{3}{|c|}{ Treatment } & \multicolumn{3}{|c|}{$\mathrm{P}$} \\
\hline & $\mathrm{HGC}$ & LGC & $\mathrm{SEM}^{1}$ & $\mathrm{~T}^{2}$ & $\mathrm{D}^{3}$ & $\mathrm{~T} \times \mathrm{D}^{4}$ \\
\hline \multicolumn{7}{|l|}{ Feed parameters in entire experiment } \\
\hline Body weight (kg) & 494 & 479 & 48 & 0.83 & $<0.001$ & 0.07 \\
\hline DMI (kg/day) & 15.2 & 10.3 & 2.7 & 0.21 & $<0.001$ & 0.25 \\
\hline $\mathrm{DMI} / \mathrm{kg}$ of body weight & 0.03 & 0.02 & 0.003 & 0.05 & $<0.001$ & 0.05 \\
\hline Crude protein $(\mathrm{CP})$ intake $(\mathrm{kg} /$ day) & 2.53 & 1.74 & 0.43 & 0.20 & $<0.001$ & 0.65 \\
\hline $\mathrm{CP} / \mathrm{kg}$ of body weight & 0.0053 & 0.0036 & 0.0005 & 0.04 & $<0.001$ & 0.23 \\
\hline Neutral detergent fiber (NDF) intake (kg/day) & 5.87 & 4.28 & 0.96 & 0.26 & $<0.001$ & 0.05 \\
\hline $\mathrm{NDF} / \mathrm{kg}$ of body weight & 0.0119 & 0.0088 & 0.0012 & 0.08 & $<0.001$ & 0.11 \\
\hline Mineral matter (MM) intake (kg/day) & 0.83 & 0.51 & 0.14 & 0.11 & $<0.001$ & 0.94 \\
\hline Ether extract (EE) intake (kg/day) & 0.47 & 0.31 & 0.08 & 0.17 & $<0.001$ & 0.42 \\
\hline Non-fiber carbohydrate $(\mathrm{NFC})^{5}$ (kg/day) & 5.52 & 3.43 & 1.09 & 0.20 & $<0.001$ & $<0.01$ \\
\hline $\mathrm{NFC} / \mathrm{kg}$ of body weight & 0.0114 & 0.0069 & 0.0016 & 0.06 & $<0.001$ & $<0.001$ \\
\hline \multicolumn{7}{|l|}{ Parameters of feed pre-partum } \\
\hline Body weight (kg) & 521 & 491 & 51 & 0.69 & 0.06 & 0.13 \\
\hline DMI (kg/day) & 10.45 & 7.30 & 1.66 & 0.23 & 0.96 & 0.80 \\
\hline $\mathrm{DMI} / \mathrm{kg}$ of body weight & 0.020 & 0.015 & 0.002 & 0.06 & 0.50 & 0.96 \\
\hline Crude protein $(\mathrm{CP})$ intake (kg/day) & 1.34 & 0.81 & 0.25 & 0.18 & 0.76 & 0.80 \\
\hline $\mathrm{CP} / \mathrm{kg}$ of body weight & 0.0025 & 0.0017 & 0.0003 & 0.10 & 0.86 & 0.95 \\
\hline Neutral detergent fiber (NDF) intake (kg/day) & 5.71 & 3.78 & 0.50 & 0.03 & 0.13 & 0.21 \\
\hline $\mathrm{NDF} / \mathrm{kg}$ of body weight & 0.0109 & 0.0078 & 0.0006 & $<0.01$ & 0.02 & 0.37 \\
\hline Mineral matter (MM) intake (kg/day) & 0.54 & 0.24 & 0.05 & $<0.01$ & 0.89 & 0.99 \\
\hline Ether extract (EE) intake (kg/day) & 0.34 & 0.22 & 0.05 & 0.14 & 0.97 & 0.78 \\
\hline Non fiber carbohydrate (NFC) ${ }^{5}$ (kg/day) & 2.51 & 2.29 & 0.95 & 0.88 & 0.60 & 0.97 \\
\hline NFC/kg of body weight & 0.0048 & 0.0044 & 0.0015 & 0.86 & 0.86 & 0.94 \\
\hline \multicolumn{7}{|l|}{ Parameters of feed and production post-partum } \\
\hline Body weight (kg) & 472 & 472 & 44 & 0.99 & 0.09 & 0.49 \\
\hline DMI (kg/day) & 19.08 & 12.65 & 3.51 & 0.23 & $<0.001$ & 0.23 \\
\hline $\mathrm{DMI} / \mathrm{kg}$ of body weight & 0.040 & 0.026 & 0.005 & 0.07 & $<0.01$ & 0.18 \\
\hline Crude protein $(\mathrm{CP})$ intake $(\mathrm{kg} /$ day) & 3.51 & 2.46 & 0.64 & 0.28 & $<0.01$ & 0.33 \\
\hline $\mathrm{CP} / \mathrm{kg}$ of body weight & 0.0074 & 0.0050 & 0.0009 & 0.10 & $<0.01$ & 0.26 \\
\hline Neutral detergent fiber (NDF) intake (kg/day) & 6.08 & 4.88 & 1.25 & 0.52 & $<0.01$ & 0.04 \\
\hline $\mathrm{NDF} / \mathrm{kg}$ of body weight & 0.0128 & 0.0101 & 0.0018 & 0.31 & $<0.01$ & 0.05 \\
\hline Mineral matter (MM) intake (kg/day) & 1.06 & 0.72 & 0.21 & 0.29 & $<0.01$ & 0.35 \\
\hline Ether extract (EE) intake (kg/day) & 0.57 & 0.38 & 0.11 & 0.23 & $<0.001$ & 0.23 \\
\hline Non-fiber carbohydrate (NFC) $)^{5}$ (kg/day) & 7.86 & 4.21 & 1.32 & 0.09 & $<0.01$ & 0.22 \\
\hline
\end{tabular}


Table 2: Continuation...

\begin{tabular}{lccllrl}
\hline $\mathrm{NFC} / \mathrm{kg}$ of body weight & 0.0166 & 0.0086 & 0.0020 & 0.02 & 0.01 & 0.18 \\
$3.5 \%$ fat-corrected milk yield (kg/day) & 26.24 & 18.96 & 4.28 & 0.26 & $<0.01$ & 0.85 \\
Milk protein yield (kg/day) & 1.05 & 0.76 & 0.12 & 0.11 & 0.02 & 0.93 \\
Milk fat yield (kg/day) & 0.93 & 0.69 & 0.17 & 0.34 & $<0.01$ & 0.73 \\
\hline
\end{tabular}

${ }^{1}$ Standard error of mean; ${ }^{2}$ Effect of treatment; ${ }^{3}$ Effect of collection day; ${ }^{4}$ Effect of the interaction between treatment and collection day; ${ }^{5} \mathrm{CNF}=100-(\mathrm{PB}+\mathrm{FDN}+\mathrm{MM}+\mathrm{EE})$.

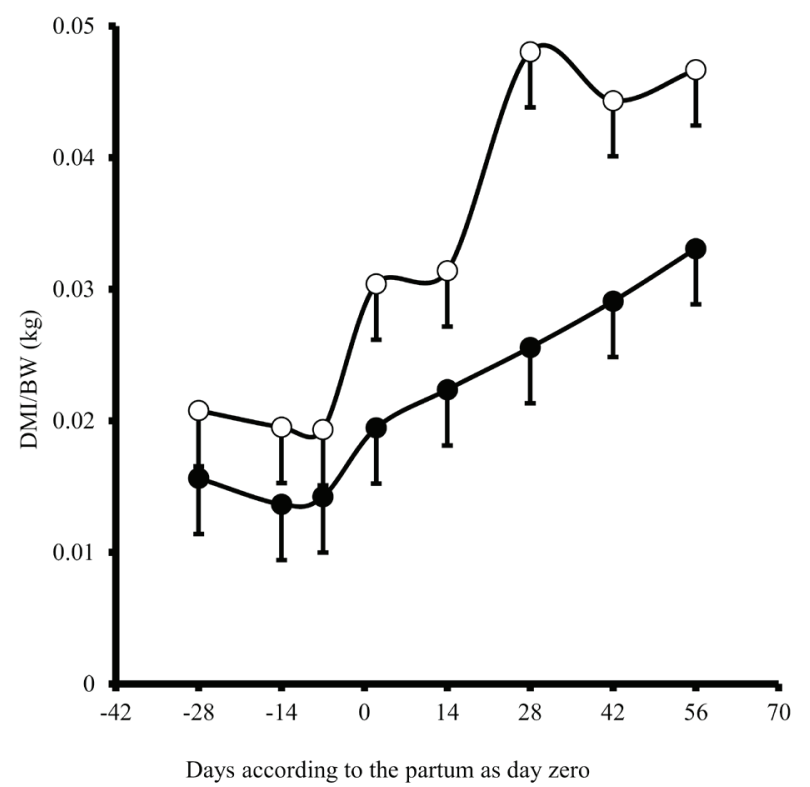

Figure 1: Dry matter intake (DMI)/kg of body weight (BW) of dairy cows fed diets containing high $(\circ)$ or low $(\bullet)$ grain content pre-partum. ( $P=0.05$ for the effect of treatment; $P<0.001$ for the effect of collection day; and $P=0.05$ for effect of the interaction between treatment and collection day).

The supply of different diets before calving did not induce a difference in rumen MI (Table 3; Figure 2). Based on the data (Figure 2), it seems that there was faster recuperation of the rumen MI when the lactation diet was introduced in the cows that received the HGC diet pre-partum than in those that received the LGC diet. However, the absence of a significant interaction between treatment and collection day shows that the similarity between the treatments was maintained over the entire the experimental period.

There was no influence of the treatments on the MI of the omasum epithelium (Table 3; Figure 3). However, there was a trend for an effect of the interaction between treatment and collection day, and this could be explained by the MI peak that occurred on the $7^{\text {th }}$ day before parturition (Figure 3 ) in the omasum epithelium of the cows that were fed the HGC diet. The MI of the omasum epithelium was higher than that of the rumen epithelium (Figure 4), demonstrating that renewal of the omasum epithelium is more intense than that of the rumen epithelium. The data presented in Figure 4 and the significant interactions between treatment, compartment and collection day (Figure 4) could suggest that the response of the mitotic index to stimuli is a little slower, but stronger, in the omasum than in the rumen.

Goodlad (1981) reported that approximately four days after the introduction of concentrate feed, rumen MI values increased. After this MI peak, there was decay, and the MI returned to a level slightly higher than the initial level. Lima et al. (2011) also found that the MI peaked in the rumen and in the omasum on the $4^{\text {th }}$ day after beginning concentrate feed. These observations could explain the reason why an MI difference between the treatments in the present experiment was not detected, because the mean data were analyzed over the entire transition period. Moreover, before parturition in the present experiment, the MI peak of the omasum epithelium occurred after the peak of the rumen. After parturition, the behavior was the same. Therefore, it seems that the response of the epithelium MI to stimuli is a little slower in the omasum than in the rumen.

Daniel and Resende Júnior (2012) also found a higher MI in the omasum epithelium than in the rumen epithelium of different breeds of adult bovines fed different diets. Moreover, there was high correlation between the MI of the rumen epithelium and the omasum epithelium, but this did not occur in the present study. These data indicate that the stimuli that induce the omasum epithelium proliferation are the same as those that induce the rumen epithelium proliferation.

The height (Table 3; Figure 5) and area (Table 3; Figure 6) of the omasum papillae in the cows that were fed the HGC diet increased one week before parturition and two weeks post-partum compared to the cows that were fed the LGC diet. This fact was demonstrated by the trend towards an interaction between treatment and 
Table 3: Morphological parameters of the rumen and the omasum of Holstein cows fed a diet containing high (HGC) or low (LGC) grain content prepartum and a highly caloric postpartum diet.

\begin{tabular}{|c|c|c|c|c|c|c|}
\hline \multirow{2}{*}{ Morphological variable } & \multicolumn{3}{|c|}{ Treatment } & \multicolumn{3}{|c|}{$\mathrm{P}$} \\
\hline & HGC & LGC & SEM $^{1}$ & $\mathrm{~T}^{2}$ & $\mathrm{D}^{3}$ & $\mathrm{~T} \times \mathrm{D}^{4}$ \\
\hline Rumen mitotic index ( $\%$ of the basal nuclei) & 0.49 & 0.50 & 0.007 & 0.09 & 0.15 & 0.17 \\
\hline Omasum mitotic index ( $\%$ of the basal nuclei) & 0.67 & 0.56 & 0.068 & 0.25 & 0.46 & 0.08 \\
\hline Height of the omasum papillae (mm) & 0.50 & 0.45 & 0.026 & 0.21 & 0.28 & 0.08 \\
\hline Area of the omasum papillae $\left(\mathrm{mm}^{2}\right)$ & 0.19 & 0.19 & 0.016 & 0.91 & 0.79 & 0.14 \\
\hline Thickness of the entire omasum epithelium $(\mu \mathrm{m})$ & 68.22 & 82.02 & 4.036 & 0.03 & 0.35 & 0.19 \\
\hline Thickness of the keratinized layer $(\mu \mathrm{m})$ & 7.37 & 9.81 & 1.13 & 0.15 & 0.21 & 0.64 \\
\hline Thickness of the non-keratinized layer $(\mu \mathrm{m})$ & 60.77 & 72.19 & 3.96 & 0.06 & 0.44 & 0.20 \\
\hline
\end{tabular}

${ }^{1}$ Standard error of the mean; ${ }^{2} \mathrm{Effect}$ of the treatments; ${ }^{3} \mathrm{Effect}$ of collection day; ${ }^{4} \mathrm{Effect}$ of the interaction between treatment and collection day.

collection day (Table 3; Figure 5). The increased height of the omasum papillae one week before parturition and two weeks post-partum reflects the omasum response to the HGC diet, as demonstrated by the trend towards an interaction effect between treatment and collection day on the omasum epithelium MI (Table 3; Figure 3). Teixeira et al. (2009) reported that the function of the omasum papillae is to help in particle retention, but their study was only descriptive and did not include any statistical analysis. The results of the present study are consistent with the likely higher VFA clearance capacity in cows provided a diet with higher grain content before parturition, which induced higher DMIBW after parturition. Although studies that measured the height and area of the omasum papillae were not found in the literature, it is widely known that the area and height of the rumen papillae respond positively to a high calorie diet, inducing a larger absorptive surface for VFAs (Melo et al., 2013; Teófilo et al., 2011; Dirksen et al., 1984; Beharka, 1998; Shen et al., 2004).

One week before parturition and two weeks postpartum, the height of the omasum papillae tended to be higher when the cows were fed the HGC diet (Figure 5), in which less abrasiveness was expected. It is known that the function of the keratinized layer is to protect the epithelium against injury from dietary abrasiveness. Accordingly, when the cows were fed the more abrasive LGC diet, the total omasum epithelium was thicker (Table 3; Figure 7), as were the non-keratinized epithelial layers (Table 3; Figure 8), most likely to supply the needs of the cells undergoing the keratinization process to maintain the renewal necessary due to desquamation. However, it was not possible to detect a significant difference $(P=0.15)$ in the thickness of the keratinized layer (Table 3).

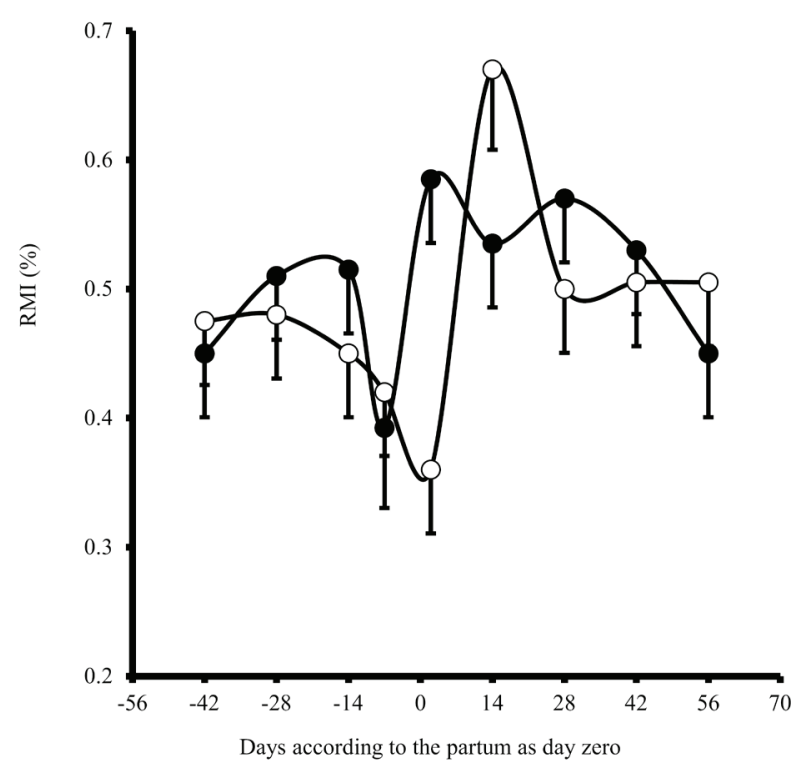

Figure 2: Mitotic index of the basal layer of the rumen epithelium (RMI) of dairy cows fed a diet containing high (O) or low $(\bullet)$ grain content pre-partum. $(P=0.86$ for effect of treatment; $P=0.15$ for effect of collection day; and $P=0.17$ for effect of the interaction between treatment and collection day).

Similar to the results of this experiment, working with goats fed a high grain diet, Liu et al. (2014) detected profound alterations in omasal epithelial structure and the expression of tight junction proteins, corresponding to a reduction in the thickness of the total epithelia, stratum granulosum, and the sum of the stratum spinosum and stratum basale associated with omasal epithelial cellular damage (Liu et al., 2014). 
However, in the present experiment, there was no evidence that the high energy diet was sufficient to cause damage to the epithelium of the rumen and omasum. The higher IMSBW and the numerically higher milk production seem to reflect the good health of the animals that received the $\mathrm{HGC}$ diet.

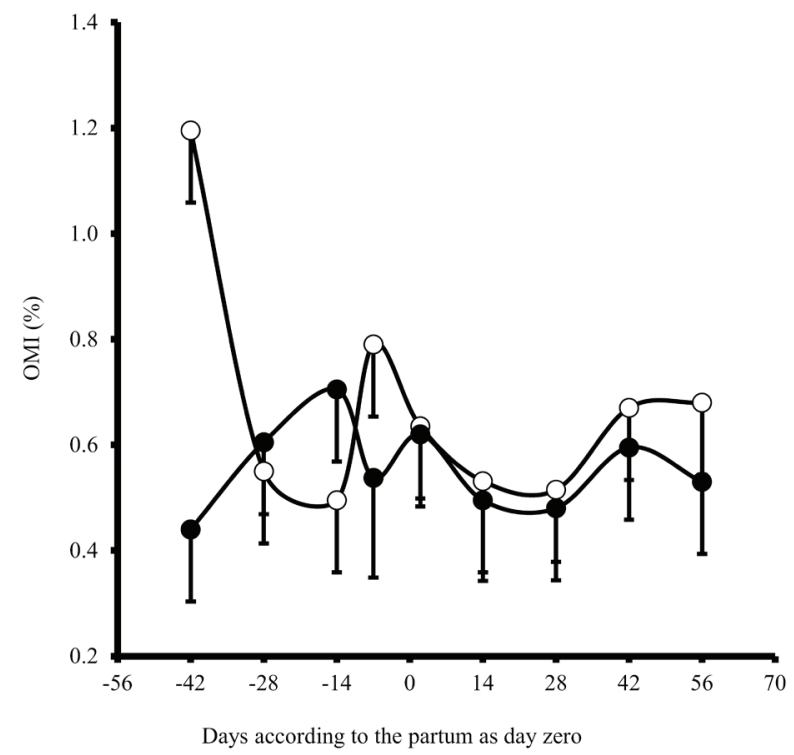

Figure 3: Mitotic index of the basal layer of the omasum epithelium (OMI) of dairy cows fed a diet containing high $(\circ)$ or low $(\bullet)$ grain content pre-partum. $(P=0.25$ for the effect of treatment; $P=0.46$ for the effect of collection day; and $P=0.08$ for effect of the interaction between treatment and collection day).

The thickness of the total epithelium (Figure 7) and the thickness of the non-keratinized layers (Figure 8) were higher in the omasum mucosa of the cows that were fed the LGC diet than in those that were fed the HGC diet pre-partum, which indicates that the increased omasum papillae height (Figure 5) and area (Figure 6) were not due to an increase in the thickness of the epithelial layers. Other factors, such as blood flow, could be involved in papillae height, which is also observed in the rumen papillae. Liu et al. (2014) also detected reduced total epithelium thickness in goats fed a high energy diet. As in the present experiment, the high energy diet resulted in a significant reduction in the thickness of the non-keratinized layers, but Liu et al. (2014) also did not detect an effect of the diet on the keratinized layer.

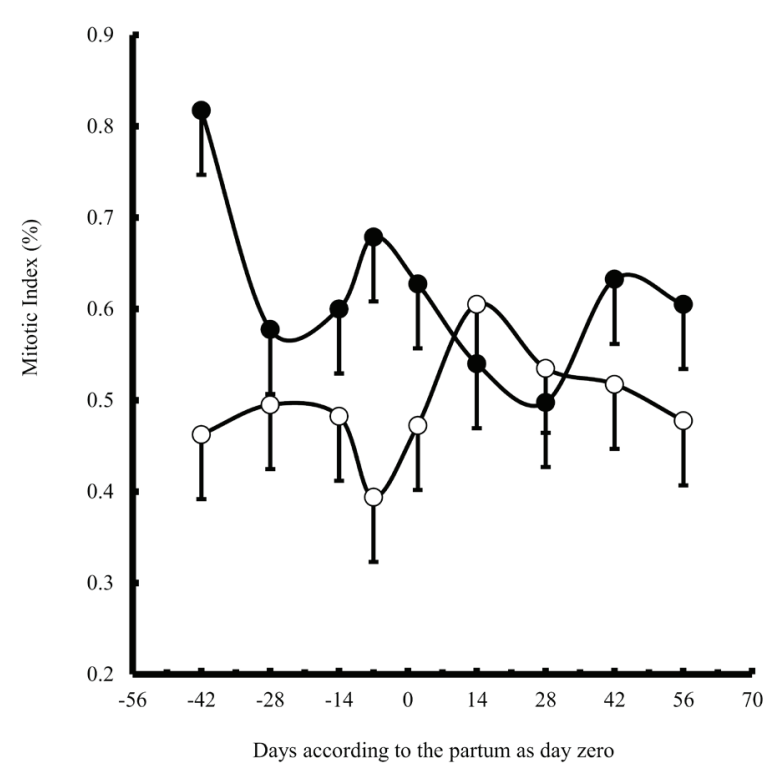

Figure 4: Mitotic index of the basal layer of the epithelium of the rumen $(\circ)$ and of the omasum $(\bullet)$ of dairy cows fed a diet containing high or low grain content pre-partum. $(P<0.001$ for the effect of compartment; $P=0.81$ for the effect of collection day; $P=0.12$ for the effect of the interaction between compartment and collection day; and $P=0.05$ for the effect of the interaction between treatment, compartment and collection day).

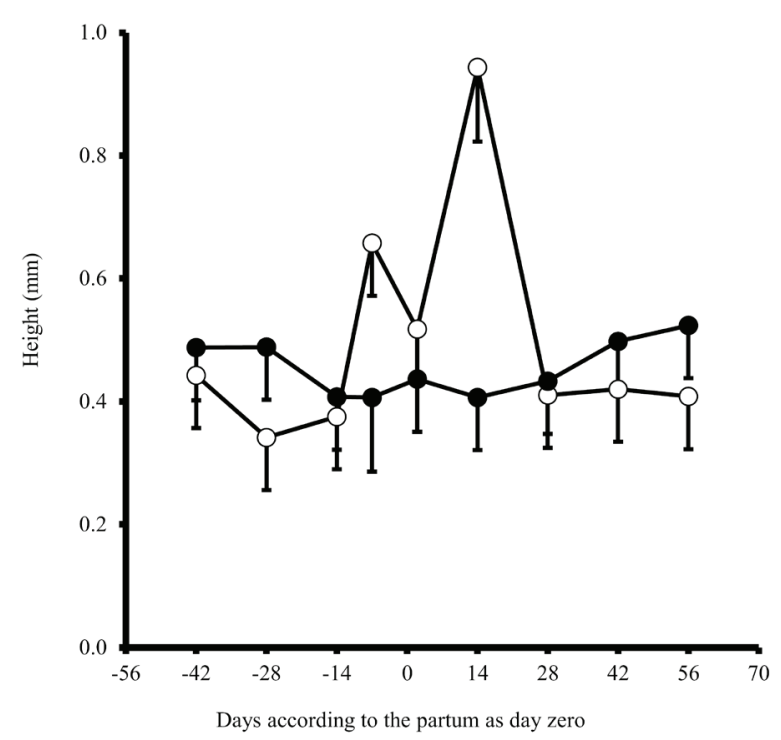

Figure 5: Height of the omasum papillae (OP) of dairy cows fed a diet containing high $(\circ)$ or low $(\bullet)$ grain content pre-partum. ( $P=0.21$ for the effect of treatment; $P=0.28$ for the effect of collection day; and $P=0.08$ for effect of the interaction between treatment and collection day). 


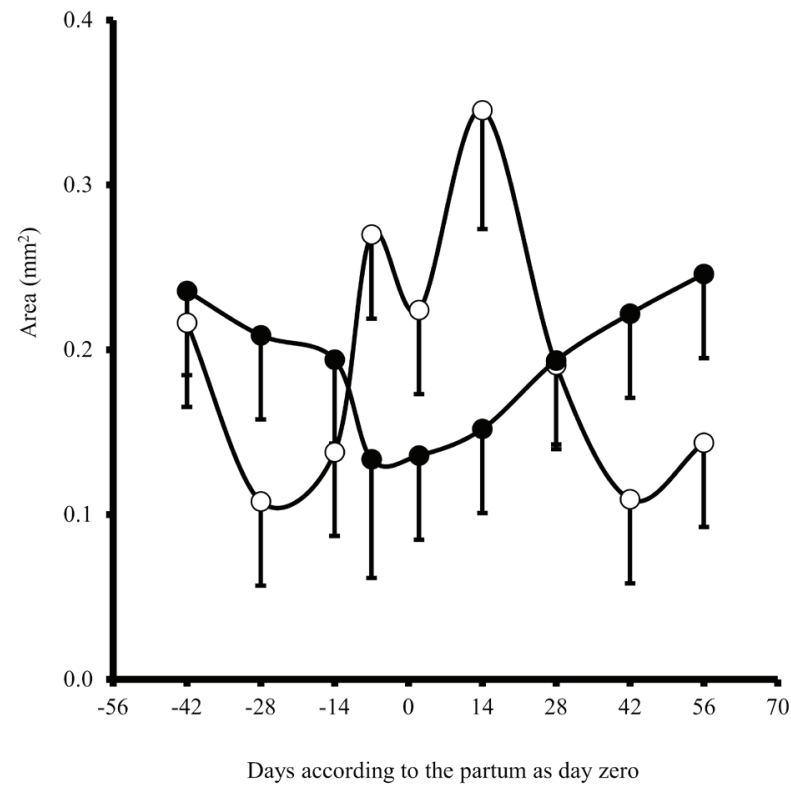

Figure 6: Area of the omasum papillae (OP) of dairy cows fed a diet containing high $(\circ)$ or low $(\bullet)$ grain content pre-partum. ( $P=0.91$ for the effect of treatment; $P=0.79$ for the effect of collection day; and $P=0.14$ for the effect of the interaction between treatment and collection day).

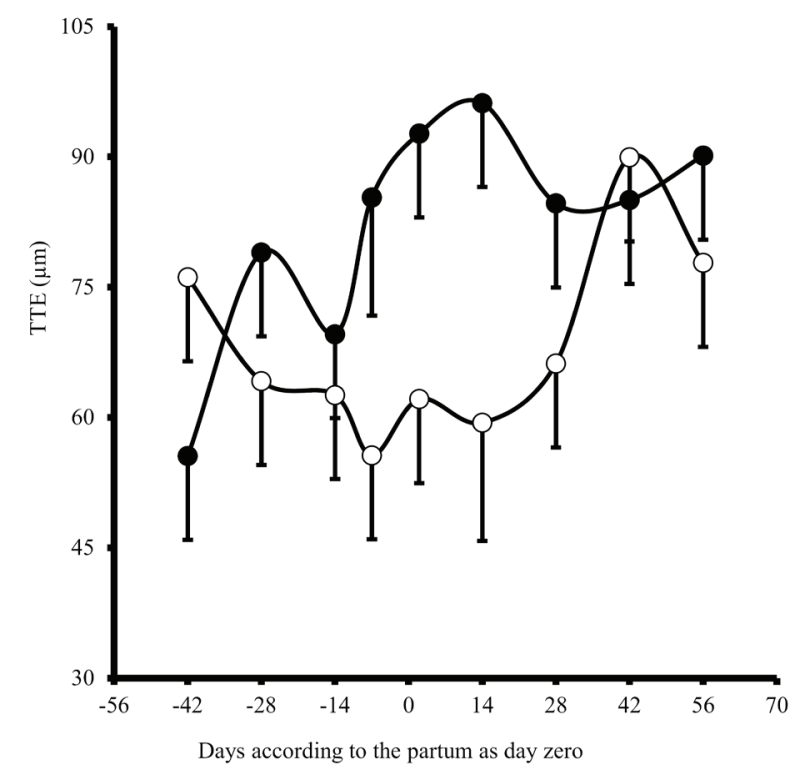

Figure 7: Total thickness of the omasum epithelium (TTE) of dairy cows fed a diet containing high ( $(0)$ or low (•) grain content pre-partum. $(P=0.03$ for the effect of treatment; $P=0.35$ for the effect of collection day; and $P$ $=0.19$ for the effect of the interaction between treatment and collection day).

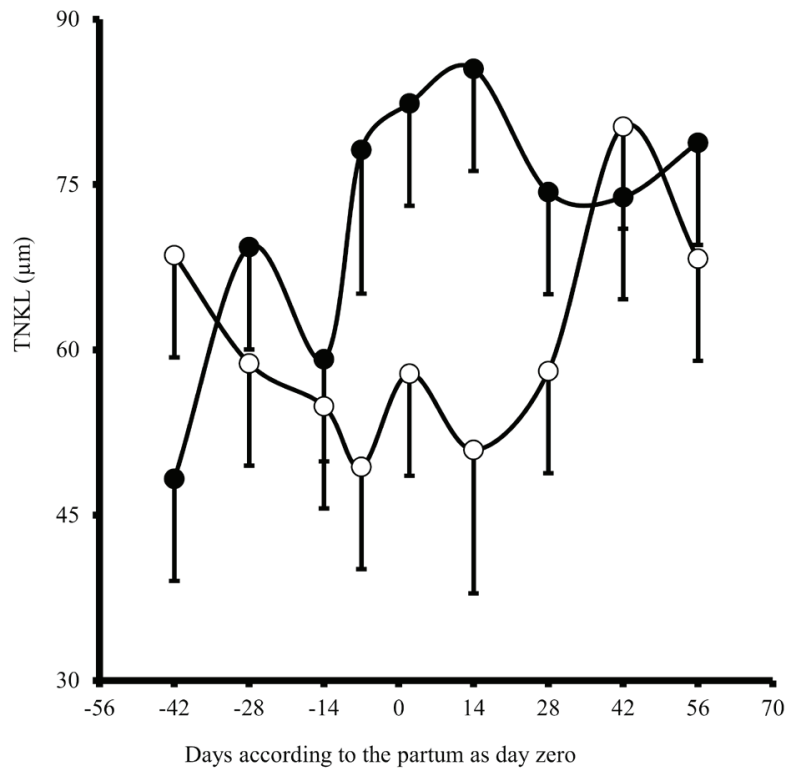

Figure 8: Thickness of the non-keratinized layers (TNKL) of the omasum epithelium of dairy cows fed a diet containing high $(0)$ or low $(\bullet)$ grain content pre-partum. $(P$ $=0.06$ for the effect of treatment; $P=0.44$ for the effect of collection day; and $P=0.20$ for the effect of the interaction between treatment and collection day).

There was a high positive correlation between the thickness of the keratinized and non-keratinized layers $\left(\mathrm{r}^{2}=0.68 ; P<0.01\right)$. According to Greenwood, Morril and Titgemeyer (1997), the keratinized layer of the ruminal epithelium tends to be thicker and represents the highest portion of the epithelium when Holstein bull calves are supplied a diet with low abrasiveness. This indicates that the extension of the keratinization of the papillae and the abrasiveness of the diet were inversely correlated, which differs from the present experiment in the omasum epithelium. Lima et al. (2011) found that the keratinized layer of the rumen epithelium was thicker than that of the omasum epithelium. However, in the study by Lima et al. (2011), the thickness of the keratinized layer of the omasum epithelium was higher than that found in the present study. Moreover, the animals utilized by Lima et al. (2011) were not under actual production conditions and had lower DMI than the animals of the present study.

Diets containing carbohydrates from concentrate feed (starch or pectin) have been shown to lead to higher rumen mucosae thickness than diets in which NDF was the carbohydrate source (Suárez et al., 2006), which is contrary to what was found in the omasum in the present experiment. Cozzi et al. (2002) have found lower rumen 
mucosae thickness in calves fed a higher NDF content diet. These data show the relation between diets containing NDF and mucosae thickness. If there is an inverse relation where higher NDF intake induces lower epithelium thickness, this could explain the result found in the present experiment because the cows fed the HGC diet pre-partum had higher NDF intake (Table 2). Furthermore, according to Sairanen et al. (2005), diets with higher concentrate content induce greater NDF passage to the omasum. However, few experiments have measured morphological variables in the omasum (Liu et al., 2014); therefore, further experiments must be conducted to elucidate this phenomenon.

\section{CONCLUSIONS}

The omasum mucosa of dairy cows responds positively to the supply of a high grain content diet before parturition, as indicated by the increased height of the omasum papillae and by the reduced thickness of the omasum epithelium. However, it seems that the mitotic index responds a little slower, but stronger, to the diet stimuli in the omasum epithelium than in the rumen epithelium. The cows that received the high grain content diet before parturition had higher dry matter and nutrient intake than the cows that received the low grain content diet, most likely reflecting the better adaptation of the rumen and omasum for higher fractional rates of VFA production.

\section{ACKNOWLEDGMENT}

The authors are grateful to the Fundação de Amparo à Pesquisa do Estado de Minas Gerais - FAPEMIG (Brazil) for financial support.

\section{REFERENCES}

BARKER, I. K.; VAN DREUMEL A. A.; PALMER, E. The alimentary system. Page 1. In: JUBB, K. V. F.; KENNEDY, P. C. Pathology of Domestic Animals. $4^{\text {th }}$ rev. ed. E Palmer, N. Academic Press, San Diego, CA, 1995. $747 p$.

BEHARKA, A. A. et al. Effects of form of the diet on anatomical, microbial, and fermentative development of the rumen of neonatal calves. Journal of Dairy Science. 81:1946-1955, 1998.

BLAXTER, K. L. Experiments on the use of home grown foods for milk production: II. The effect of feeding concentrated and bulky foods before calving on subsequent milk production. Journal of Agricultural Science. 34:27-28, 1944.
BOLTEN, J. R. et al. Normal abomasal electromyography and emptying in sheep and the effects of intraabomasal volatile fatty acid infusion. American Journal of Veterinary Research. 37:1387-1388, 1976.

COZZI, G. L. et al. The provision of solid feeds to veal calves: I. Growth performance, forestomach development, and carcass and meat quality. Journal of Animal Science. 80:357-366, 2002.

CRICHLOW, E. C.; CHAPLIN, R. K. Ruminal lact acidosis: Relationship of forestomach motility to nondissociated volatile fatty acids levels. American Journal of Veterinary Research. 46:1908-1911, 1985.

DANIEL, J. L. P.; RESENDE JÚNIOR, J. C. Absorption and metabolism of volatile fatty acids by rumen and omasum. Ciência e Agrotecnologia. 36:93-99, 2012.

DIRKSEN, G. et al. Morphologie der pansenschleimhaut und fettsäureresorption beim rind - bedeutende faktoren für gesunkheit und leistung. Zentralbl Veterinarmed. 31:414-430, 1984.

ELLIOT, J. P. et al. Utilization of supplemental fat by dairy cows fed diets varying in content of nonstructural carbohydrates. Journal of Dairy Science. 78:15121525, 1995.

GÄBEL, G.; ASCHENBACH, J. R.; MULLER, F. Transfer of energy substrates across the ruminal epithelium: implications and limitations. Animal Health Research Review. 3:15-30, 2002.

GOODLAD, R. A. Some effects of diet on the mitotic index and the cell cycle of the ruminal epithelium of sheep. Quarterly Journal of Experimental Physiology. 66:487-499, 1981.

GRANT, R. J.; MERTENS, D. R. Influence of buffer $\mathrm{pH}$ and raw cornstarch addition on in vitro fiber digestion kinetics. Journal of Dairy Science. 75:27622768, 1992.

GREENWOOD, R. H.; MORRILL, J. L.; TITGEMEYER, E. C. A new method of measuring diet abrasion and its effect on the development of the forestomach. Journal of Dairy Science. 80:2534-254, 1997. 
GRUMMER, R. R. Impact of changes in organic nutrient metabolism on feeding the transition dairy cow. Journal of Animal Science. 73:2820-2833, 1995.

GUO, J.; PETERS, R. R.; KOHN, R. A. Effect of a transition diet on production performance and metabolism in periparturient dairy cows. Journal of Dairy Science. 90:5247-5258, 2007.

LIMA, R. F. et al. Morphological response of the ruminal and omasal mucosae to the variation in the energy of the diet. Journal of Dairy Science. 94(E-Suppl. 1):648-648, 2011.

LIU, J. H. et al. A high-grain diet alters the omasal epithelial structure and expression of tight junction proteins in a goat model. The Veterinary Journal. 201:95-100, 2014.

MELO, L. Q. et al. Rumen morphometrics and the effect of digesta $\mathrm{pH}$ and volume on volatile fatty acid absorption. Journal of Animal Science. 91:1775-1783, 2013.

NATIONAL RESEARCH COUNCIL. Nutrient requirements of dairy cattle. Washington: National Academy, 2001.731p.

RESENDE JÚNIOR, J. C. et al. Comparison of techniques to determine the clearance of ruminal volatile fatty acids. Journal of Dairy Science. 89:3096-3106, 2006.

SAIRANEN, A. et al. The effect of concentrate supplementation on nutrient flow to the omasum in dairy cows receiving freshly cut grass. Journal of Dairy Science. 88:1443-1453, 2005.

SHEN, Z. et al. An energy-rich diet causes rumen papillae proliferation associated with more IGF type 1 receptors and increased plasma IGF-1 concentrations in young.

Journal of Nutrition. 134: 11-17, 2004.

SUÁREZ, B. J. et al. Effects of supplementing concentrates differing in carbohydrate composition in veal calf diets: II. Rumen development. Journal of Dairy Science. 89:4376-4386, 2006.

SVENDSEN, P. Etiology and pathogenesis of abomasal displacement in cattle. Nordisk Veterinaer Medicin. 21(Sup. 1). 1-1, 1969.

TEIXEIRA, A. F. et al. Functional morphology of unguiculiform papillae of the reticular groove in the ruminant stomach. Annals of Anatomy. 191:469-476, 2009.

TEÓFILO, T. S. et al. Morphology of the rumen of dairy cows fed high or low grain content diets before parturition. Journal of Dairy Science. 94 (E-Suppl 1). 630-631, 2011. 